\title{
Comparison Between The Suspension and Capsule Preparation from Waste of Avocado Seeds As Antidiarrhea in Induced Mouse
}

\section{Muharni Saputri*, Nilsya Febrika Zebua, Fivi Nur Asih, Ghera Fakhira Putri}

Department of Pharmacy, Faculty of Pharmacy, Universitas Tjut Nyak Dhien, Gg. Rasmi No.28, Sei Sikambing C. II, Medan Helvetia, Medan, North Sumatra 20123, Indonesia

\section{Abstract}

Diarrhea is one type of disease with the most sufferers every year. Thus, it is considered an endemic disease in Indonesia and the potential disease of Extraordinary Events accompanied by mortality. One of the plants that can be used as a traditional medicine for diarrhea is the avocado seed, as it contains tannins, alkaloids, flavonoids, steroids and glycosides, which act as antidiarrheals. This study aims to determine the antidiarrheal effect of avocado seed extract suspension on mice induced by Oleum ricini and the optimum concentration of avocado seed extract suspension and capsules with an antidiarrheal effect in white male mice induced by Oleum ricini. The dosage forms chosen were suspension and capsules. This study used an experimental method with a test sample of the avocado seed. Avocado seed Simplicia was extracted by the percolation method, then an oral suspension and capsule formulation were made from the avocado seed methanol extract. It was evaluated and tested for its effectiveness with mice to cure diarrhea. Normal data were analyzed by One Way ANOVA and Post Hoc Tuckey Method. The results of this study showed that the administration of a suspension of avocado seed methanol extract at a dose of $800 \mathrm{mg} / \mathrm{KgBB}$ had the most optimum effect as an antidiarrheal against white male mice with a stool weight of 0.39 grams and a duration of diarrhea for 74 minutes. Furthermore, the administration of avocado seed extract capsules at a dose of 75 $\mathrm{mg} / \mathrm{KgBB}$ had the most optimum effect as antidiarrheal against white male mice with Loperamide as a positive control. Therefore, it can be concluded that all suspension formulations and capsules of avocado seed methanol extract met the requirements for preparation evaluation. Suspension and avocado seed methanol extract capsules can cure diarrhea in white male mice.

Keywords: Antidiarrheal; Avocado Seeds; Oleum ricini; Suspension; Capsule

\section{INTRODUCTION}

Diarrhea in Indonesia has become an endemic disease and is a potential

\section{Data of article}

Received : 28 Dec 2021

Reviewed : 28 Jan 2022

Accepted : 14 Feb 2022

DOI

10.18196/jfaps.v2i1.13504

Type of article:

Research 
modern medicine. People prefer traditional medicine that uses plants as this type of treatment has fewer side effects than conventional preparations. One of the traditional treatments is using avocado (Persea Americana Mill.) Avocado seeds contain alkaloids, tannins, triterpenes, and quinones. ${ }^{2}$ Avocado seed waste can be used for traditional medicine by drying and then mashing. Empirically, avocado seeds are used as medicine to treat diarrhea, diabetes medicine, cholesterol medicine and treat toothache.

There are various pharmaceutical preparations, such as capsules and suspensions. Researchers chose capsules and suspension preparations to investigate the antidiarrheal effect of methanol extract of avocado seeds (Persea Americana Mill.). Capsules that mask unpleasant tastes and odors are easy to consume and prepare. The medicinal ingredients are protected from external influences (light, humidity). Powder formulations often require the addition of fillers, lubricants, and glides to the active ingredients to facilitate the capsule filling process. Capsules are solid preparations consisting of a soluble hard or soft shell drug; the shell is generally made of gelatin, starch, or other suitable materials. The extracts were made using the percolation method. 3 Meanwhile, the suspension is widely used as it is easy to use for children, infants, and adults who have difficulty swallowing tablets or capsules. Suspensions can also be added with additives to mask the unpleasant taste of the active substance. In general, the liquid form is preferred over the tablet or capsule form as it is easy to swallow and adjust the dose for children. ${ }^{4}$ The advantages of these two preparations are that they are practical to provide comfort for drug consumers and can cover unpleasant tastes and odors in drugs. 5
Based on the description of the background, this study aims to identify whether there is a difference between the suspension and capsules of avocado seed methanol extract that meets the physical quality requirements of the preparation and to determine whether the suspension and capsules of avocado seed methanol extract (Persea Americana Mill.) had an antidiarrheal effect. Furthermore, this study also aims to identify the optimum concentration of avocado seed methanol extract that can have an antidiarrheal effect on mice.

\section{METHOD}

This research is an experimental study with a sample of avocado seeds (Persea Americana Mill.). The chemicals used in this study were Avocado Seed, Na CMC, Simple Syrup, Loperamide $\mathrm{HCl}$, Oleum ricini, distilled water, $\mathrm{HCl}$, Bouchardat reagent, Dragendroff reagent, Fehling's reagent $A$, Fehling's reagent $B_{1} \mathrm{HNO}_{3}$, Mayer's reagent, Molish's reagent, $\mathrm{NaOH}$, $\mathrm{Pb}\left(\mathrm{C}_{2} \mathrm{H}_{3} \mathrm{O}_{2}\right)$, Lieberman-Bouchardat reagent and $\mathrm{HNO}_{3} \cdot \mathrm{FeCl}_{3}$

\section{Making Simplicia and Extract}

Simplicia was made by cleaning avocado seeds from dirt, then dried in a drying cabinet at a temperature of $\pm 40^{\circ} \mathrm{C}$. It was then mashed and weighed of the dry powder obtained. The next step was to make methanol extract of avocado seeds by the percolation method. The procedure for making extracts in the percolation process was that the dry powder of avocado seeds was weighed as much as 500 grams and first soaked for 24 hours with $1200 \mathrm{ml}$ of methanol in a closed glass vessel and dark in color. The extraction process was continued in a percolator, and the solvent used was $2.305 \mathrm{~L}$ to the liquid that dripped from the clear percolator. The percolate liquid was allowed to drip while the filtered 
fluid was added repeatedly; thus, the filtered fluid limit remained $10 \mathrm{~cm}$ above the simplicia powder. The percolate yield obtained was $2.100 \mathrm{~L}$. The percolation process was carried out until the percolate liquid no longer gave a cloudy color. The percolation results were evaporated in a vaporizer cup covered with aluminum foil and given a small hole. It was left in an open room for a week until the solvent evaporated and obtained a thick extract. The extract was later weighed.

\section{Phytochemical Screening}

Phytochemical screening was carried out qualitatively on avocado seed Simplicia powder (Persea Americana Mill.), including examination of alkaloids, flavonoids, tannins, saponins, glycosides, cyanogenic glycosides, anthraquinone glycosides, steroids/triterpenoids.

\section{Preparation Evaluation}

\section{Organoleptic Examination}

Organoleptic examination of the suspension and capsules of avocado seed methanol extract included color, odor, taste and texture.

An avocado seed methanol extract suspension was an organoleptic examination that included a light brown color, characteristic aromatic odor, sweet taste, and sandy texture.

Organoleptic examination of avocado seed methanol extract capsules included dark brown color, aromatic odor, bitter taste and gritty texture.

\section{Stability Test}

The stability evaluation for the suspension was carried out by the cycling test method. It was accelerated storage under forced conditions, carried out by storing at $40 \mathrm{C}$. Furthermore, it was put in the refrigerator and stored at $400 \mathrm{C}$ in the oven alternately for 24 hours for 6 cycles with organoleptic test parameters (color), odor, dosage form, and the $\mathrm{pH}$ of the preparation.

\section{Viscosity Test}

The suspension viscosity measurement was carried out after reconstituted using a Brookfield viscometer spindle number 1 at a speed of 30 RPM. Before and after accelerated storage conditions, the shear stress was calculated.

\section{Sedimentation Test}

The measurement of the sedimentation volume of the suspension has been made before and after accelerated storage conditions. It was carried out by comparing the sediment's final volume (Vu) with the original (Vo) before deposition. The redispersion ability would be good if the suspension was completely dispersed when shaken by hand for a maximum of 30 seconds.

\section{Specific Weight Test}

Specific gravity is the ratio of the weight of the substance to water in the same volume, which is weighed at room temperature before and after being given accelerated storage conditions at $5^{\circ} \mathrm{C}$ and $35^{\circ} \mathrm{C}$ for 12 hours each for 5 cycles.

a. Use a clean and empty pycnometer, then fill it with distilled water; the outside of the pycnometer is dried and weighed

b. Discard the distilled water, dry the pycnometer and then fill it with liquid syrup at the same temperature and at the time of measurement of distilled water and weigh it.

Formula: $\rho=\frac{m}{V}$

Information :

$\rho=$ Density $\left(\mathrm{g} / \mathrm{cm}^{3}\right)$ or $(\mathrm{g} / \mathrm{ml})$

$\mathrm{M}=$ Mass of object $(\mathrm{g})$

$\mathrm{V}=$ Volume of object $\left(\mathrm{cm}^{3}\right)$ or $(\mathrm{ml})$ 


\section{pH Test preparation}

Evaluation of the preparation's $\mathrm{pH}$ was carried out using a calibrated $\mathrm{pH}$ meter. The suspension was put in a beaker glass, and then the $\mathrm{pH}$ meter was dipped into the suspension. The $\mathrm{pH}$ value of the suspension was identified by looking at the numbers listed on the $\mathrm{pH}$ meter.

\section{Weight Uniformity Test}

Thoroughly, 10 capsules were weighed one at a time and identified. The contents of each capsule in an appropriate manner were then removed.

\section{Destroyed Time Test}

6 capsules were inserted in each tube in the basket under the 10 mesh steel plates. The medium water temperature of $37^{\circ} \mathrm{C}$ was then used. In the observation of the capsules, all capsules must be crushed, except for part of the capsule shell.

\section{Hygroscopicity Test}

A total of 3 capsules was placed in a brown bottle and stored in a desiccator. Each treatment was observed every day for seven days and every week for a month. Observations were made on changes in capsule weight, capsule shape, and capsule contents.

\section{Experimental Animal Preparation}

The test animals used in this study were adult mice (Mus musculus) weighing 20-30 grams. The total sample was 25 mice divided into 5 groups. Each treatment group consisted of 5 mice. Group 1 was a negative control, group 2 was a positive control, and groups 3, 4, and 5 were treatment groups. Two weeks before the experiment, the mice were adapted to the experimental environment.

\section{Antidiarrheal Effectiveness Test}

The dose of avocado seed methanol extract given to experimental animals used a dose ratio with loperamide. In a positive control group, loperamide $\mathrm{HCl}$ was used. Oleum ricini was used as induction, and four test groups were given suspension and capsules of avocado seed methanol extract with three dose ratios. It was given to 25 mice adapted to the research environment for 1 week. Before the study was conducted, the mice fasted for 18 hours while still being given water before testing. They were grouped into 5 groups; each group consisted of 5 mice. All mice were given Oleum ricini as a diarrhea induction of $0.75 \mathrm{ml}$ per mouse orally except for the normal group.

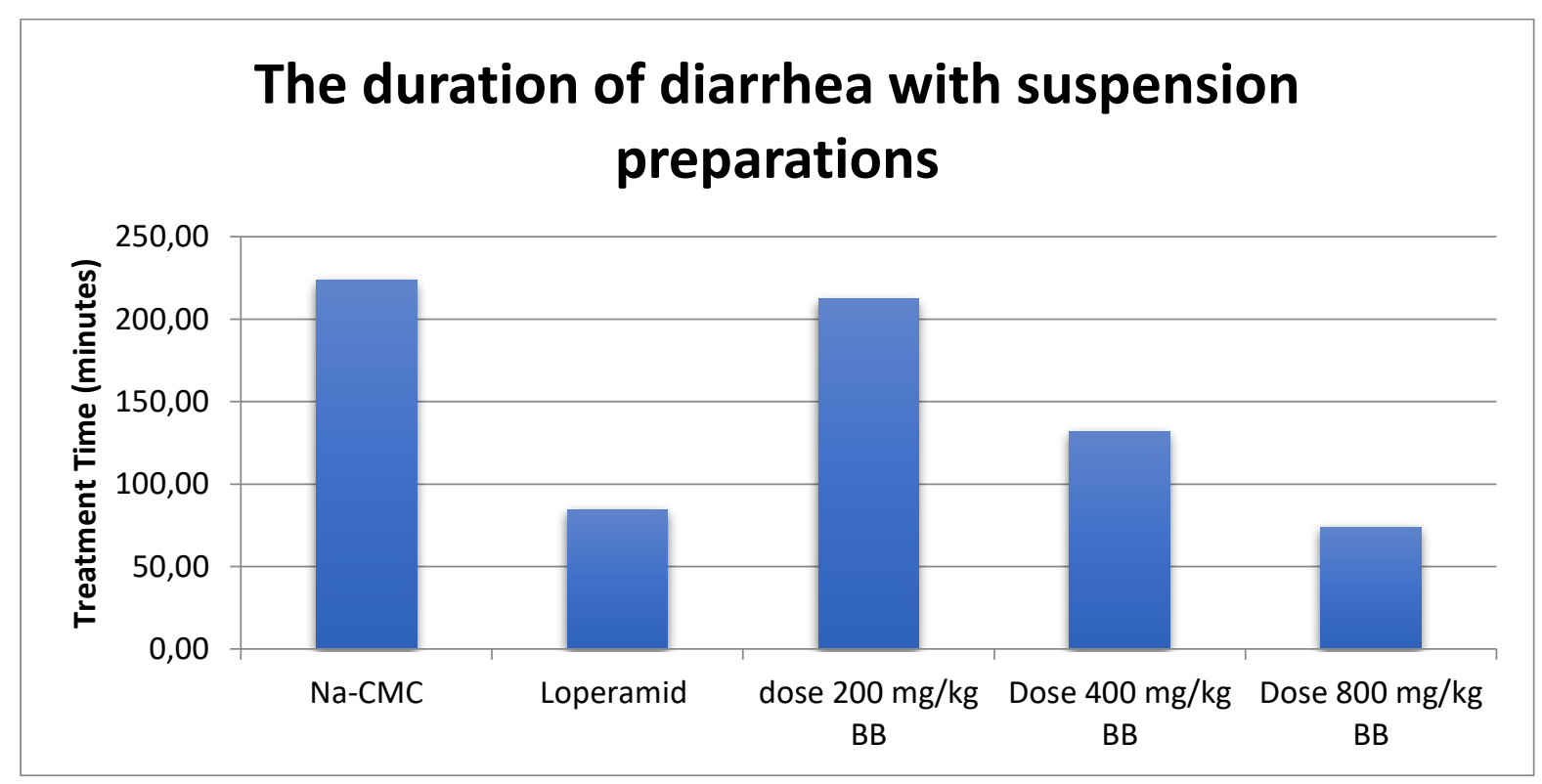

Grafic 1. Grafic of duration of diarrhea in suspensions preparations 


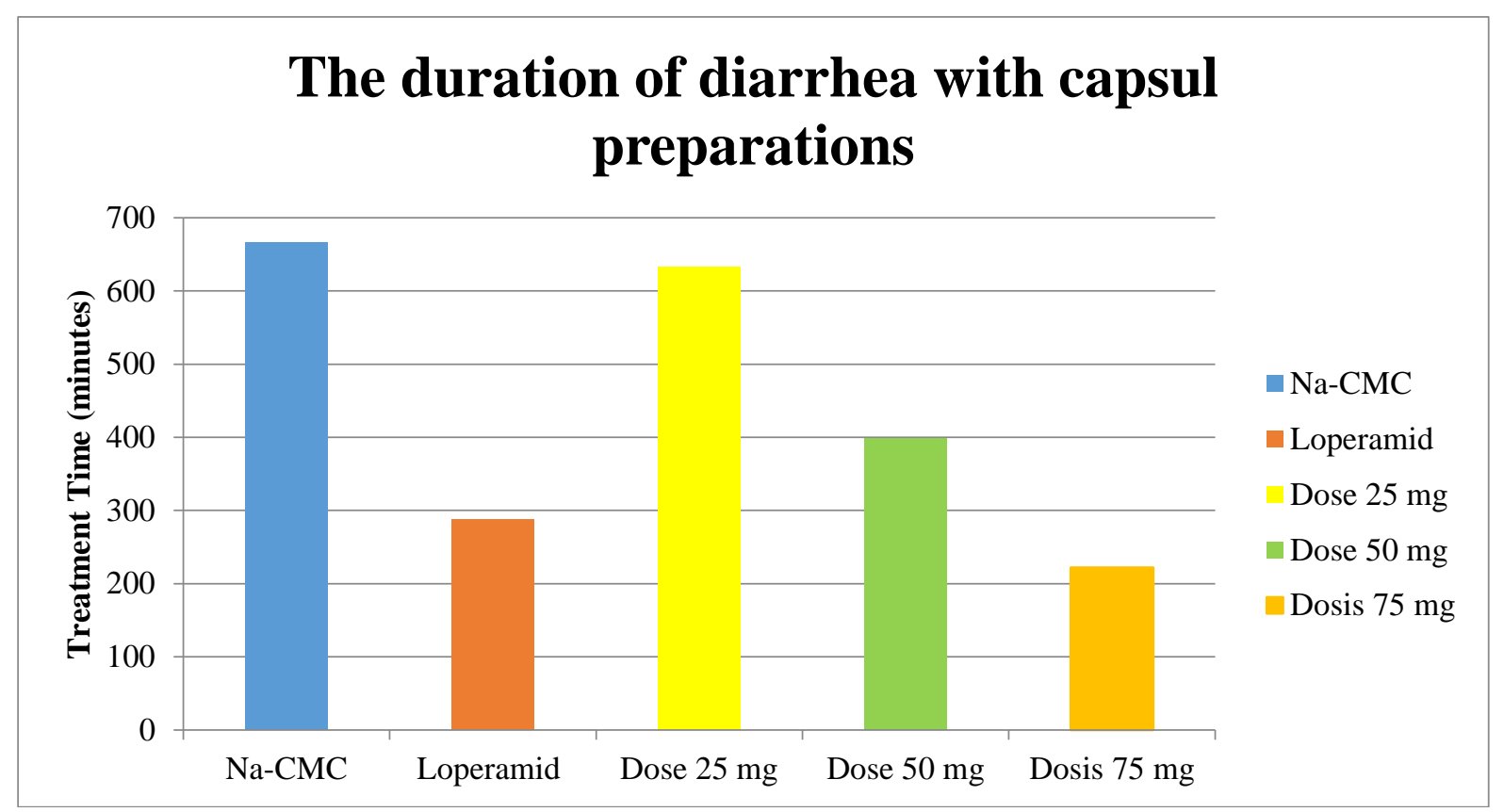

Grafic 2. Grafic of duration of diarrhea in capsule preparations

After being given Oleum ricini as much as $0.75 \mathrm{ml}$ per head as an inducer, the capsule and suspension were left for 30 minutes. It was then given the test material orally according to each group of animals. The antidiarrheal effect was determined by

\section{RESULTS AND DISCUSSION}

Phytochemical Screening Results observing the onset of diarrhea, the frequency of feces, the weight of the feces in grams, and the duration of diarrhea. In this experiment, the antidiarrheal effect was observed for 5 hours.

Table 1. Phytochemical Screening Results

\begin{tabular}{lcl}
\hline \multicolumn{1}{c}{ Compound Group } & $\begin{array}{c}\text { Content of Dried } \\
\text { Avocado Seed } \\
\text { Simplicia }\end{array}$ & \multicolumn{1}{c}{ Phytochemical Screening Results } \\
\hline Alkaloids & + & $\begin{array}{l}\text { Mayer: Dark Chocolate } \\
\text { Draendroff: Muddy Chocolate } \\
\text { Bouchardat: Cloudy Yellow }\end{array}$ \\
Saponins & + & White Foam \\
Flavonoids & + & Red Orange \\
Tannins & + & Blackish Green \\
Glycoside & + & Glycon: Purplish brown/purple in the middle \\
Anthraquinone glycosides & - & Pink/Red \\
Cyanogenic Glycoside & - & Blood red on filter paper \\
Steroids & + & Green
\end{tabular}




\section{Test Results of Avocado Seed Methanol Extract Suspension on Mice with Post Tukey}

Table 2. Test Results of Fecal Weight when Given Avocado Seed Methanol Extract Sustenance

\begin{tabular}{llllllll}
\hline \multirow{2}{*}{ Treatment } & \multicolumn{3}{c}{$\begin{array}{l}\text { Fecal Weight (Gram) } \\
\text { Repetition }\end{array}$} & Amount & \multicolumn{1}{c}{$\begin{array}{c}\text { Average } \\
\text { (Gram) }\end{array}$} & $\begin{array}{c}\text { Statistical } \\
\text { Result } \\
\text { RAL }\end{array}$ \\
\cline { 2 - 5 } & 1 & 2 & 3 & & & \\
\hline Na-CMC & 0.62 & 0.6 & 0.41 & 1.63 & 0.543333333 & \\
Loperamid HCl & 0.31 & 0.31 & 0.24 & 0.86 & 0.286666667 & \\
Dosage of $200 \mathrm{mg} / \mathrm{kgBB}$ & 0.29 & 0.4 & 0.61 & 1.3 & 0.433333333 & 0.526 \\
Dosage of 400 mg/kg BB & 0.27 & 0.38 & 0.73 & 1.38 & 0.46 & \\
Dosage of 800 mg/kg BB & 0.25 & 0.26 & 0.67 & 1.18 & 0.393333333 & \\
\hline
\end{tabular}

Table 3. Results of the Post Tukey Fecal Frequency Test when Suspended with Avocado Seed Methanol Extract

\begin{tabular}{llc}
\hline \multirow{2}{*}{ Treatment } & N & Subset for alpha $=\mathbf{0 . 0 5}$ \\
\cline { 3 - 3 } & & $\mathbf{1}$ \\
\hline Dosage of $400 \mathrm{mg}$ & 3 & 9.6667 \\
Dosage of $800 \mathrm{mg}$ & 3 & 10.0000 \\
Loperamide $\mathrm{HCl}$ & 3 & 10.3333 \\
Dosage of 200mg & 3 & 10.3333 \\
Na_CMC & 3 & 12.3333 \\
Sig. & & 0.299 \\
\hline
\end{tabular}

Table 4. Post Tukey Test Results in Fecal Weight when Given Avocado Seed Methanol Extract Sustenance

\begin{tabular}{llc}
\hline \multirow{2}{*}{ Treatment } & N & Subset for alpha $=0.05$ \\
\cline { 3 - 3 } & & $\mathbf{1}$ \\
\hline Loperamide $\mathrm{HCl}$ & 3 & 0.2867 \\
Dosage of 800 mg & 3 & 0.3933 \\
Dosage of 200mg & 3 & 0.4333 \\
Dosage of 400 mg & 3 & 0.4600 \\
Na_CMC & & 0.5433 \\
Sig. & & 0.436 \\
\hline
\end{tabular}

Test Results of Avocado Seed Methanol Extract Suspension on Mice with Post Tukey

Table 5. Diarrhea Results When Given Avocado Seed Methanol Extract Capsules

\begin{tabular}{lcccccc}
\hline \multirow{2}{*}{ Treatment } & \multicolumn{3}{c}{ Fecal Weight (Gram) } & & Average \\
\cline { 2 - 4 } \cline { 2 - 4 } & \multicolumn{3}{c}{ Repetitation } & & \multirow{2}{*}{ Amount } & (Gram) \\
\cline { 2 - 4 } & 0.75 & 0.72 & 0.42 & & 1.89 & 0.63 \\
Na-CMC & 0.23 & 0.23 & 0.17 & & 0.63 & 0.21 \\
Loperamid & 0.22 & 0.25 & 0.61 & & 1.08 & 0.36 \\
Dosage of $25 \mathrm{mg}$ & 0.27 & 0.32 & 0.61 & & 1.2 & 0.4 \\
Dosage of $50 \mathrm{mg}$ & 0.27 & 0.39 & 0.36 & & 1.02 & 0.34 \\
Dosage of 75 mg & & & & & \\
\hline
\end{tabular}


Table 6. Results of the Post Tukey Test of Feces Frequency when Given Avocado Seed Methanol Extract Capsules

\begin{tabular}{llc}
\hline \multirow{2}{*}{ Treatment } & N & Subset for alpha $=\mathbf{0 . 0 5}$ \\
\cline { 3 - 3 } & & $\mathbf{1}$ \\
\hline Loperamide HCl & 3 & 8.0000 \\
Dosage of $800 \mathrm{mg}$ & 3 & 8.0000 \\
Dosage of 200mg & 3 & 9.0000 \\
Dosage of 400 mg & 3 & 10.0000 \\
Na_CMC & 3 & 12.0000 \\
Sig. & & 0.211 \\
\hline
\end{tabular}

Table 7. Post Tukey Test Results in Fecal Weight when Given Avocado Seed Methanol Extract Capsules

\begin{tabular}{llcc}
\hline \multirow{2}{*}{ Treatment } & $\mathbf{N}$ & \multicolumn{2}{c}{ Subset for alpha=0.05 } \\
\cline { 3 - 4 } & & $\mathbf{1}$ & $\mathbf{2}$ \\
\hline Loperamide HCl & 3 & 0.2100 & \\
Dosage of $800 \mathrm{mg}$ & 3 & 0.3400 & 0.3600 \\
Dosage of $200 \mathrm{mg}$ & 3 & & 0.4000 \\
Dosage of 400 mg & 3 & & 0.6300 \\
Na_CMC & 3 & & 0.221 \\
Sig. & & 0.581 & \\
\hline
\end{tabular}

Based on the results of phytochemical screening of avocado seed methanol extract, it is known that avocado seeds contain a group of compounds such as alkaloids, saponins, flavonoids and tannins. Alkaloid compounds work by inhibiting the growth of Salmonella typhimurium bacteria which have been known to have the potential to cause diarrhea. ${ }^{6}$ Meanwhile, tannin compounds are astringent, which can help stop diarrhea. ${ }^{7}$ Flavonoids are antidiarrhea with the mechanism of inhibiting intestinal motility by reducing fluid and electrolytes. Another flavonoid activity (quercetin) is by inhibiting the release of acetylcholine in channel. ${ }^{8}$

Furthermore, the results of organoleptic observations included odor, color, and taste which were observed every 14 days. In each suspension formula of Avocado seed methanol extract, organoleptic changes occurred in the suspension. There is a change in taste in the table due to a fermentation reaction. Fermentation is the main energy-producing process of various microorganisms. The following table measuring $\mathrm{pH}$ Meter.

Table 8. Table Measuring $\mathrm{pH}$ Mater

\begin{tabular}{ccc}
\hline \multirow{2}{*}{ Replication } & \multicolumn{3}{c}{$\mathrm{pH}$ Meter } \\
\cline { 2 - 3 } & $\begin{array}{c}\text { Before the suspension was made } \\
(\mathrm{pH})\end{array}$ & $\begin{array}{c}\text { After the suspension was made } \\
(\mathrm{pH})\end{array}$ \\
\hline $\mathrm{F}_{1}$ & 4.8 & 4 \\
$\mathrm{~F}_{2}$ & 4.7 & 3.7 \\
$\mathrm{~F}_{3}$ & 4.5 & 3.8 \\
\hline Average & 4.75 & 3.83 \\
\hline
\end{tabular}


The $\mathrm{pH}$ test results were tested by shelflife. It revealed the suspension formulation with the suspending agent $\mathrm{CMC} \mathrm{Na}$. The $\mathrm{pH}$ decreased from 4.75 to 3.83 during the storage cycle, and the optimum suspension $\mathrm{pH}$ was 5-6.9 The $\mathrm{pH}$ of the preparation was acidic due to the presence of additives (preservatives). It was used in the form of benzoic acid with a $\mathrm{pH}<4.5$ to affect the $\mathrm{pH}$ of the preparation. Meanwhile, the specific gravity measurement results showed a change in the specific gravity of the suspension before and after the accelerated storage conditions from 1.03 to 1.02, which met the suspension-specific gravity requirements, namely $>1.00$ $\mathrm{g} / \mathrm{ml}^{10}$

Table 9. Table measuring $\mathrm{pH}$ Meter

\begin{tabular}{ccc}
\hline & \multicolumn{2}{c}{$\mathrm{pH}$ Meter } \\
\cline { 2 - 3 } Replication & Before the suspension was made & $\begin{array}{c}\text { After Accelerated Storage } \\
\text { Conditions } \\
(\mathrm{pH})\end{array}$ \\
\hline $\mathrm{F}_{1}$ & 4.8 & 4 \\
$\mathrm{~F}_{2}$ & 4.7 & 3.7 \\
$\mathrm{~F}_{3}$ & 4.5 & 3.8 \\
\hline Average & 4.75 & 3.83 \\
\hline
\end{tabular}

Based on the results of statistical tests on observing the initial diarrhea time with ANOVA testing, a significance value was 0.366 ( $p>0.05) .{ }^{11}$ Furthermore, Ho was accepted, indicating that the five treatments had unequal variances (not homogeneous), which could be concluded to accept Ho. It meant that the average value of diarrhea in each of these treatments was not significantly different. ${ }^{12}$

The decision-making of the Tukey method can be carried out by looking at the placement of the statistical test results in the column. The test results for the duration of diarrhea at a dose of $800 \mathrm{mg}$ were in the same column as loperamide which concluded that the diarrhea value in each treatment was not significantly different. Meanwhile, a dose of $200 \mathrm{mg}$, $400 \mathrm{mg}$ and $\mathrm{Na}-\mathrm{CMC}$ are in different columns, indicating that the diarrhea value in each treatment was significantly different from the positive control group. ${ }^{13}$

Furthermore, in the statistical test results in the column, the results of the frequency of diarrhea at a dose of $400 \mathrm{mg}$, a dose of $800 \mathrm{mg}$, Loperamide, a dose of $200 \mathrm{mg}$ and $\mathrm{Na}-\mathrm{CMC}$ were in the same column, concluding that the value of diarrhea in each of these treatments was not significantly different. The results of the loperamide stool weight at a dose of 800 $\mathrm{mg}, 200 \mathrm{mg}, 400 \mathrm{mg}$ and $\mathrm{Na}-\mathrm{CMC}$ were in the same column, concluding that the value of diarrhea in each of these treatments was not significantly different. Meanwhile, the results of the frequency of diarrhea at a dose of $50 \mathrm{mg}$, loperamide, a dose of $75 \mathrm{mg}, 25 \mathrm{mg}$ and $\mathrm{Na}-\mathrm{CMC}$ were in the same column, concluding that the diarrhea value in each treatment was not significantly different. ${ }^{14}$

The results of the $75 \mathrm{mg}$ dose of feces and loperamide were in the same column, indicating that, in each treatment, it was not significantly different (Significant). However, it was significantly different at $25 \mathrm{mg}, 50 \mathrm{mg}$ and $\mathrm{Na}-\mathrm{CMC}$. Meanwhile, the $50 \mathrm{mg}$ dose, $25 \mathrm{mg}$ dose and $\mathrm{Na}-\mathrm{CMC}$ were in the same column, indicating that the diarrhea value at $50 \mathrm{mg}$ dose, $25 \mathrm{mg}$ dose and $\mathrm{Na}-\mathrm{CMC}$ was not significantly 
different. The results of the frequency of diarrhea at a dose of $50 \mathrm{mg}$, loperamide, a dose of $75 \mathrm{mg}$, a dose of $25 \mathrm{mg}$ and $\mathrm{Na}$ $\mathrm{CMC}$ were in the same column, indicating that the diarrhea value in each treatment was not significantly different. ${ }^{15}$

\section{CONCLUSION}

Based on the result of this study, it can be concluded that the results of the study indicated that avocado seeds contained alkaloids, flavonoids, glycosides, and saponins compounds. The extract yield obtained was $17.23 \%$, and the water content was 3.7. The results of the preparation evaluation tests, such as $\mathrm{pH}$ testing on formulas I, II, and III, respectively, were $4.8 ; 4.7 ; 4.5$. The average formula-specific gravity measurement was 1.03 before accelerated storage. After accelerated storage, it was 1.02. Furthermore, the result of the viscosity measurement was 199.8, while the result of the sedimentation volume measurement was $0.76 ; 0.8 ; 0.8$. \%. The administration of avocado seed methanol extract suspension at a dose of $800 \mathrm{mg} / \mathrm{kg}$ BW had the most optimum effect as an antidiarrheal against white male mice with a stool weight of 0.39 grams and a duration of diarrhea of 74 minutes. The test results were slightly different between the dose of $800 \mathrm{mg} / \mathrm{kg} \mathrm{bb}$ and Loperamide as a positive control. In addition, the results of preparation evaluation tests such as weight uniformity testing in formulas 1, 2 and 3 were $120 \mathrm{mg}$. The results of the average disintegration time of 3 minutes showed that the formula was destroyed, and the hygroscopicity test results on the three formulas were relatively stable. Furthermore, the administration of avocado seed extract capsules at a $75 \mathrm{mg} / \mathrm{kg}$ BW dose had the most optimum effect against white male mice as an antidiarrheal agent. The results of the average disintegration time were 3 minutes. The formula was then destroyed, and the hygroscopicity test results on the three formulas were relatively stable.

\section{ACKNOWLEDGMENT}

The researcher would like to thank the Institute for Research and Community Service, Tjut Nyak Dhien University, Medan, for all their support in this research.

\section{REFERENCES}

1. Artaya, P. Uji Anova Maternal Health Book. Surabaya: Naratoma University Press; 20gAD. https://doi.org/10.36733/medicament 0.V1i1.724

2. Suena, N. M. D. S. Evaluasi Fisik Sediaan Suspensi Dengan Kombinasi Suspending Agent Pga (Pulvis Gummi Arabici) DAN CMC-Na (Carboxymethylcellulosum Natrium). J Ilm Medicam. 2015;1(1):33-8.

3. Departemen Kesehatan RI. Farmakope Indonesia. Edisi III. Jakarta: Departemen Kesehatan Rl; 1971.

4. Ansel, H. Pengantar Bentuk Sediaan Farmasi, Edisi IV. Jakarta: Universitas Indonesia; 1989.

5. Fajar, I. R., \& Cahyo, H. Uji Aktivitas Ekstrak Etanol Daun Sawo Manila (Manilkara Zapota L) Sebagai Antidiare Terhadap Mencit Putih Jantan (Mus musculus). IONTech. 2020;01(1):17-25.

6. Fatmawati, U. Formulasi Suspensi Analgesik-Antipiretik Ibuprofen Dengan Suspending Agent Gom Arab Dan Cmc-Na. J Pharm Care Anwar Med. 2018;1(1):35-48. 
https://doi.org/10.36932/j-

pham.vii1.3

7. Halimah, A. D. Pengolahan Limbah Biji Alpukat untuk Pembuatan Dodol Pati Sebagai Alternatif Pengobatan Ginjal. J Ilm Mhs Undip. 2014;4(1):334 .

8. Malangngi, L., Sangi, M., Paedong, J. Penentuan Kandungan Tanin dan Uji Antioksidan Ekstrak Biji Buah Alpukat (Persea americana Mill.). J MIPA. 2012;1(1):5-10.

https://doi.org/10.35799/jm.1.1.2012. 423

9. Nyimas, F. N. The Activity Of Antibacterial Agent Of Honey Against Staphylococcus Aureus. Jurnal Majority, Universitas Lampung 2014 :96- 98.

10. Patala, R., Dewi, N. P., Pasaribu, M. $\mathrm{H}$., Efektivitas Ekstrak Etanol Biji Alpukat (Persea americana Mill.) Terhadap Kadar Glukosa Darah Tikus Putih Jantan (Rattus novergicus) Model Hiperkolesterolemia-Diabetes. Jurnal Farmasi Galenika. 2020;6(1): 7-13. https://doi.org/10.22487/j24428744.2 020.v6.i1.13929

11. Sani, F. Efektivitas Ekstrak Daun Remek Daging (Hemagraphis colorata Hall F.) Sebagai Antidiare Pada Mencit Jantan. Jurnal Borneo Journal of Pharmascientech. 2017; 01(1): 18-27.

12. Sukmawati, I. K., Sukandar, E. Y., Kurniati, N. F. Aktivitas Antidiare Ekstrak Etanol Daun Suji (Dracaena angustifolia Roxb). Pharmacy Journal. 2017i 14(2): 173-187. https://doi.org/10.30595/pharmacy.v1 4 i 2.1948

13. Wulandari, F., Widyawati, F. A., Rizaldi, K., Syaputri, F. N.Formulasi dan Evaluasi Fisik Sediaan Kapsul Ekstrak Daun Cincau Hijau (Cyclea barbata Miers) Sebagai Anti Inflamasi.As-Syifaa Jurnal Farmasi. 2020;12(2): 150-157. https://doi.org/10.33096/ja.v12i2.638 14. Wirasti., Ulfah, F., Slamet. Karakterisasi Sediaan Suspensi Nanopartikel Ekstrak Etanol Daun Afrika (Vernonia amygdalina Del.) Cendekia J Pharm. 2020;4(2):138-48. https://doi.org/10.31596/cjp.v4i2.107

15. Zulkifli, J., \& Mukhlis, R. Test OfEffect Antidiare Extract Leaf Prasman (Eupatorium Triplinerve Vahl.) On Rats Of Wistar Train (Rattus Norvegicus). Maj Farm. 2017;14(1):18. 